\title{
The soil types of the modernized, diagnostic based Hungarian Soil Classification System and their correlation with the World reference base for soil resources
}

\author{
Erika MICHÉLI ${ }^{1}$, ÁdÁm CSORBA ${ }^{1}$, TAMás SZEGI ${ }^{1}$, Endre DOBOS² and Márta FUCHS ${ }^{1}$
}

\begin{abstract}
The traditional genetic-based Hungarian Soil Classification System (HSCS) was elaborated during the 1960s. The concept and the units were developed before sufficient data and modern data processing tools became available. The 39 soil types were defined as group of soils developed under similar soil forming factors and processes, resulting in similar morphogenetic properties. The allocation of soils in the system included some subjective elements, even with substantial knowledge and experience of the classifier. The modernized "diagnostic" system was developed based on the accumulated data and experiences with the genetic system as well on the application of new pedometric tools. The definitions and limits of the diagnostic categories (horizons and properties) correspond with the World reference base for soil resources (WRB), but are not identical, they are much simpler, and adopted for the environmental setting of the Carpathian Basin. The 15 soil types (central units) are defined by the newly introduced classification key, based on diagnostic criteria, assuring a more objective result of the classification process. This paper is presenting the rational of the diagnostic system, gives a summary description of the 15 new soil types and discusses the successful correlation with the (WRB).
\end{abstract}

Keywords: soil classification, genetic approach, diagnostic approach, World Reference Base for soil resources (WRB), correlation

\section{Introduction}

In the past few decades the understanding of the global nature of environmental problems created a need for international, harmonized maps and database. The long-term target is a global classification system (HempeL, J. et al. 2013; MichéLi, E. et al. 2016; Hughes, P. et al. 2017), however, for the time being, correlation of the units of national systems is essential. Most international databases, maps and related publications, including the European Soil Database (ESDB) (Panagos, P. 2006) and the Soil Atlas of Europe (Jones, A. et al. 2005) are based on the World reference base for soil resources, the accepted correlation tool for soil scientists (IUSS Working Group WRB, 2006).
Since most systems have their own principles and definitions, simple one to one translation of national units to the WRB is not possible. Generally, reclassification of original data, expert knowledge and, or pedometric applications (mostly taxonomic distance calculations) are applied for the correlation (MinAsNY, B. et al. 2009; LÁng, V. et al. 2010).

The traditional genetic-based Hungarian Soil Classification System (HSCS) was elaborated during the 1960s. The concept and the units were developed before sufficient data and modern data processing tools became available. The 39 soil types were defined as group of soils developed under similar soil forming factors and processes, resulting in similar morphogenetic properties

\footnotetext{
${ }^{1}$ Department of Soil Science and Agrochemistry. Szent István University, H-2100 Gödöllő, Páter K. u. 1. E-mails: micheli.erika@mkk.szie.hu, csorba.adam@mkk.szie.hu; szegi.tamas@mkk.szie.hu, fuchs.marta@mkk.szie.hu ${ }^{2}$ Institute of Geography and Geoinformatics, University of Miskolc. H-3515 Miskolc, Egyetemváros. E-mail: ecodobos@uni-miskolc.hu
} 
(Stefanovits, P. 1963; Szabolcs, I. 1966). The allocation of soils in the system included some subjective elements even with substantial knowledge and experience of the classifier. MichéLI, E. et al. (2006) reported also correlation problems of certain units with international standards. The modernized "diagnostic" system was developed based on the accumulated data and experiences with the genetic system as well on applications of new pedometric tools (FucHs, M. et al. 2011; LÁNG, V. et al. 2013; MichÉLI, E. et al. 2014). The definitions and limits of the diagnostic categories (horizons, properties and materials) are based on stronger and numerical criteria than the previous system. Although the categories are not identical with, but most of them correspond with the World reference base for soil resources (WRB) (IUSS Working Group WRB, 2015). Furthermore, the definitions are, much simpler (as simplicity was among the principles of the modernization) and adopted for the environmental setting of the Carpathian Basin. The new 15 soil types are defined by the newly introduced classification key, based on the diagnostic criteria, assuring a more objective result of the classification and correlation processes (MichéLI, E. et al. 2014). In this paper we provide and discuss the correlated WRB units for the soil types of the modernized, diagnostic-based Hungarian Soil Classification System to help better communication and data exchange on international forums.

\section{Materials and methods}

The methods of the modernization efforts of the Hungarian Soil Classification System included: linking the processes to diagnostics (MichéLI, E. et al. 2011), review and pedometric evaluation of the taxonomic relationships of the genetically defined units (Fuchs, M. et al. 2011; LánG, V. et al. 2013), the development of the new central units (15 soil types), the development of the classification key, and the definition of the methodology to derive the lower level (subtype and variety) units. The 15 new soil types are the result of merging similar genetic soil types and introducing new soil types, not existing in the genetic system (MichéLI, E. et al. 2014).

The current official correlation system and the tool for development of harmonized soil information products is the WRB $3^{\text {rd }}$ edition (IUSS Working Group WRB, 2015). On the highest level 32 reference soil groups (RSG) are distinguished and defined by the key, based on the required diagnostic criteria. The RSG level was applied for the correlation of the HSCS soil types. The lower level combinations with the qualifiers are countless and are not in the scope of the present paper. For the definition of the correlated HSCS soil types with the WRB RSGs, simple reviews, expert knowledge and in some cases pedometric tools were applied (LÁNG, V. et al. 2010; MichÉLI, E. et al. 2016).

\section{Results and discussion}

The simplified classification key for the 15 soil types and the most likely correlated WRB RSGs are given in Figure 1. (The HSCS soil type names are written in bold.) For the correlated WRB RSGs the most likely correlated unit is given. Additional less common options are given in bracket. Short discussion for the correlation of each soil type is coming below.

\section{Peat soils}

Peat soils of Hungary are organic soils that commonly developed in local water-logged depressions. As a result of long-term water saturation undecomposed or partially decomposed biomass of the wetland habitats has been accumulated. In higher altitude locations, with cool climate, the peat material may consist of undecomposed moss fibres. The defined thickness $(\geq 40 \mathrm{~cm})$, depth (starts from $40 \mathrm{~cm}$ from the surface) and organic carbon content $(O C \geq 20 \%)$ are criteria of the organic layer(s), provide easy correlation with the WRB Histosols. Peats overlying ice, or 


\begin{tabular}{|c|c|c|}
\hline Soils having organic horizon(s) that consist of undecomposed or partially decomposed organic residues $(0 \mathrm{C} \geq 20 \%)$, \\
with a thickness of $\geq 40 \mathrm{~cm}$, starting $\leq 40 \mathrm{~cm}$ from the soil surface. \\
\hline Seat soils \\
\hline Soils under intensive anthropogenic influence that resulted in the admixture of organic/mineral materials, \\
in the formation of new soil horizons/layers, or in the transformation/alteration of the original soil horizons.
\end{tabular}

\begin{tabular}{|c|c|c|}
\hline Alkalic ( $\mathrm{pH} \geq 8.5$ ) soils with a soluble salt accumulation horizon (water soluble salt content $\geq 1 \%$ ) within $50 \mathrm{~cm}$ from the soil surface. \\
\hline Solonchak soils \\
\hline Heavy clay soils (clay $\geq 30 \%$ ), shrinking and swelling due to alternating dry and wet conditions, with special morphology \\
(slickenslides, wedge shaped aggregates, cracks that open and close periodically). \\
\hline Swelling clay soils
\end{tabular}

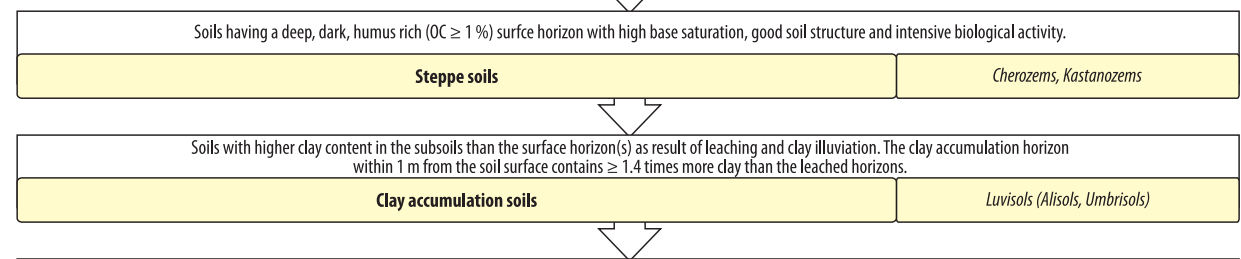

Soils having a weighted average texture class of sand or loamy sand over a depth of $1 \mathrm{~m}$ from the soil surface, or to a depth of a cemented or indurated layer, whichever is shallower.

\begin{tabular}{|c|c|}
\hline Sandy soils & Arenosols \\
\hline
\end{tabular}

\begin{tabular}{|c|c|}
\hline Soils in early stage of developement, but already showing alteration in colour, or presence of soil structure, or carbonate translocation compared to the parent material. \\
\hline Brown earth & Cambisols (Umbrisols, Calcisols) \\
\hline \begin{tabular}{|c|} 
Stratified soils of transported materials of various origin. Stratification starts within $50 \mathrm{~cm}$ from the soil surface, and is evidenced by variation \\
in texture/coarse fragment content, different colours or non regular depth distribution of organic matter.
\end{tabular} \\
\hline Sediment soils & Fluvisols, Colluvic Regosols \\
\hline Other, generally shallow, weakly developed soils developed on unconsolidated parent material or on fragmented hard rock. \\
\hline Barren earth & Regosols \\
\hline
\end{tabular}

Fig. 1. The simplified classification key for the 15 soil types of the modernized, diagnostic based HSCS and the most likely correlated WRB (2015) RSGs. 
continuous hard rock are not documented in Hungary, hence such situations are not part of the definition of peat soils and have no relevance for correlation with the WRB shallow Histosol options (criterion 1. in the WRB key).

\section{Anthropogenic soils}

The group of anthropogenic soils is a newly introduced soil type in the modernized HSCS. The soil type combines soils under intensive anthropogenic influence that resulted in the admixture of organic/mineral materials (>20\%), in the formation of new soil horizons/ layers, or in the transformation/alteration of the original soil horizons within $100 \mathrm{~cm}$ from the soil surface. The HSCS Anthropogenic soils may correlate with the Anthrosols and/or Technosols reference soil groups of WRB. The precise correlation, however, is only possible with the application of the qualifiers in both systems (eg. Terric, Linic etc.). Farsang, A. et al. (2015) contributed to the development of the concept and definitions of the anthropogenic soils. Since these soils were not part of the traditional Hungarian system, experiences with application are limited.

\section{Shallow rocky soils}

Typical soils of the steep, highly eroded surfaces of mountainous regions of Hungary, where continuous hard rock is starting $\leq 10 \mathrm{~cm}$ from the soil surface, and rock outcrops are common. The depth criteria provide a one-to-one correlation with Lithic or Nudilithic "versions" of the WRB Leptosols. Since these soils occupy less than 0.5 per cent of the country it is considered to combine them with the Lithogenic soils of the HSCS.

\section{Lithogenic soils}

Lithogenic soils include the Rendzinas, Rankers and Erubase soils of the former genetic system (Stefanovits, P. 1963), in which no specific depth criteria are defined. The modified definition of these shallow, rocky soils fully corresponds with the WRB Leptosols definition (having continuous hard rock, starting $\leq 25 \mathrm{~cm}$ from the soil surface; or high amount of coarse fragments (fine earth $<20 \%$ ) over a depth to $75 \mathrm{~cm}$ or to the bedrock). The traditional names are preserved on the lower level of the classification with the application of the subtype qualifiers.

\section{Solonetz soils}

Both Solonetz and Solonchak soils are typical for lowland areas with high evaporation rate. Their characterization, classification and mapping have long traditions in Hungary, and the achievements of Hungarian scientists influenced the classification of salt-affected soils globally (Szabolcs, I. 1989; Tо́тн, T. and VÁrallyay, G. 2002). Solonetz soils are defined by the presence of high amount of adsorbed sodium and/or magnesium, and the strongly structured columnar subsurface horizon. In the WRB the natric horizon is defined on 2 pages with several alternatives and sub-criteria. The HSCS has a simplified definition, however, the criteria for the exchangeable sodium percentage ESP $\geq 15$, or $\mathrm{Na}+\mathrm{Mg}>25$ per cent, and the similar morphological criteria provides easy correlation with the WRB Solonetz soils.

\section{Solonchak soils}

Solonchaks are alkaline $(\mathrm{pH} \geq 8.5)$ soils with high accumulation and concertation of soluble salts at, or close to the surface. Due to the limited biological activity and bioturbation, Solonchaks show moderate genetic horizon development in the subsoil. The original stratification of the fluvial or lacustrine sediments is commonly preserved. The criteria for the salt accumulation horizon (water soluble salt content $\geq 1 \%$ within $50 \mathrm{~cm}$ from the soil surface) is defined by using the standard Hungarian unit for salt content, but with the application 
of a conversion factor developed by FILEP, G. (1999) successful correlation with the WRB Solonchak RSG is possible. Soils that do not meet the salt criterion, hence the EC requirement may correspond with other WRB RGSs (eg. Gleysols or Fluvisols), however, the salt accumulation can be indicated with the Protosalic $(\mathrm{EC} \geq 4 \mathrm{dS} / \mathrm{m})$ qualifier in the correlation.

\section{Swelling clay soils}

"Swelling clay soils" are newly introduced to the modernized HSCS. They may form in different landscapes from fluvial depositions to mountain pediments and were allocated in different genetic soil types (alluvial soils, meadow soils, "erubaz" soils (soils of volcanic origin), however, the common characteristics are the high clay content $(\geq 30 \%)$, and shrinking and swelling properties due to alternating dry and wet conditions. The corresponding criteria for the clay content and for the special morphology (slickensides, wedge shaped aggregates, cracks that open and close periodically) within $1 \mathrm{~m}$ from the soil surface, provide a one-to-one correlation with the Vertisols RSG of the WRB.

\section{Meadow soils}

The genetically defined "meadow soils" are groundwater-affected soils of lowland areas with redoximorphic features (STEFANOvits, P. 1963; Szabolcs, I. 1966). However, the lack of the criteria for depth and expression for the colour patterns allowed subjectivity in the classification and correlation process. With the introduction of the definition of reducing condition, the gleyic colour pattern and depth criteria, correlation with WRB is easier. Meadow soils with periodic reducing conditions within $50 \mathrm{~cm}$ from the soil surface, and evidences of the gleyic colour patterns in more than 50 per cent of the matrix between $50-100 \mathrm{~cm}$ from the soil surface likely correlate with the WRB Gleysols. Other groundwater influenced soils with deeper re- doximorphic features may correspond with other WRB RSGs but can be specified with the Gleyic qualifier in the correlation process.

\section{Carbonate soils}

Carbonate soils are also new in the modernized HSCS. These soils have high amount of $\mathrm{CaCO}_{3}$ (calcium carbonate equivalent $\geq 25 \%$ ) within $50 \mathrm{~cm}$ from the soil surface. This high amount of mostly secondary carbonates have generally weathered or have been leached from the primary parent material (i.e. from limestone, loess, marl). The secondary accumulation of carbonates is often combined with erosion ("bringing" accumulations close to the surface). Significant part of Hungary is a carbonate rich basin, where carbonate soils can develop in various soil forming environments from hill sediments to eroded loess plateaus. Since the amount and the depth criteria of carbonates of the HSCS Carbonate soils are much stronger than the WRB Calcisols, the correlation is not straight forward. Most HSCS Carbonate soil fulfil the requirements of the WRB Calcisols, however, only a portion of WRB Calcisols correspond with the HSCS Carbonate soils.

\section{Steppe soils}

The traditional Dokuchaev Chernozem concept (DokUchaev, V.V. 1883) influenced most genetic-based national classification systems. As result of substantial surveys, new knowledge, as well as degradation processes, changes occurred in the classification of the deep, dark steppe soils (soils developed under grassland vegetation). In the WRB four RSGs are dedicated to soils with high organic matter content in the dark mineral surface soils: The Chernozems and Kastanozems (secondary carbonate present at shallow depths), the Phaeozems (secondary carbonate leached to a depth $\geq 50 \mathrm{~cm}$ below the organic matterrich mineral top horizon) and the low base Umbrisols. In the Carpathian Basin most of 
the Steppe soils formed on loessy parent material and have deep, dark OC reach surface horizons and subsurface horizons with secondary carbonates. The criteria of the humusrich surface horizon corresponds with that of the WRB mollic horizon in terms of depth $(20 \mathrm{~cm})$, colour (Munsell chroma $\leq 3)$, base saturation $(\geq 50 \%)$, and favourable structure, however, based on the statistical studies of national data sets (LÁNG, V. 2013), in the classification key of the diagnostic based HSCS stronger criteria was set for OC content $(\geq 1 \%)$ for the Steppe soils, similarly to WRB chernic horizon for the Chernozems. This allows satisfactory correlation of the HSCS unit with the lighter coloured WRB Kastanozems and the darker Chernozems. The close taxonomic relationship is evident, however, not all WRB Kastanozems and Chernozems satisfy the HSCS Steppe soil criteria - as in the HSCS key the presence of $>20$ per cent coarse fragments to $50 \mathrm{~cm}$ depth, or continuous rock or clay accumulation horizon within $1 \mathrm{~m}$ are also excluded from Steppe soils. As these soils represent the most fertile soils of Hungary (VÁrAllyay, G. et al. 1985) further fine-tuned studies are going on for nomenclature (the Steppe soil name is not satisfactory for the authors) and the lower level specifications.

\section{Soils with clay accumulation}

In the traditional genetic approach clay accumulation soils were listed among the brown forest soils in many countries, at the same time other members of brown forest soils were often confused with clay accumulation soils (CLINE, M.G. 1949; Tavernier, R. and Smiths, D.G. 1957). In most modern soil classification systems clay accumulation soils are representing individual classes and do not preserve forest related nomenclature. In the modernized diagnostic based HSCS the criteria for the presence of the clay accumulation horizon is corresponding with WRB argic horizon in terms of depth (within $1 \mathrm{~m}$ ) of the clay enriched horizon and clay increase $(1.4 \% \times$ compared to the leached horizons) and the requirements of clay skins in case of truncated, ploughed or polygenetic soils (with lithological differences). This allows an easy correlation of the HSCS Clay accumulation soils with the Luvisols of the WRB. In forested areas where clay accumulation soils develop deep, high OC containing surface horizons, they may correlate with the WRB Umbrisols. In limited areas where the acidification processes are intensive and the effective base saturation of the clay accumulation horizon is $<50$ per cent, the Alisols RSG may be the corresponding WRB unit.

\section{Sandy soils}

Sandy soils of Hungary are typically weakly developed soils, have low amount of organic and inorganic colloids, which resulted in unfavourable physical-, chemical properties and low fertility. These soils have a weighted average texture class of sand or loamy sand to a depth of $1 \mathrm{~m}$ from the soil surface, or to a depth of a cemented or indurated layer, whichever is shallower. These criteria are fully matching the WRB Arenosols reference group, providing an easy correlation. In cases when sand is covering other soils or layers with contrasting texture, correlation is more complicated and requires decisions based on the specific situation.

\section{Brown earths}

Brown earth was the other typical member of brown forest soils in the genetic based system (Stefanovits, P. 1963; Szabolcs, I. 1966). However, the insignificant subsurface horizonation may develop in different soil forming environment (JennY, H. 1941; Cline, M.G. 1949; TAvernier, R. and Smiths, D.G. 1957). Hence in the WRB and most other systems soils showing slight alteration in colour and soil structure compared to the parent material are listed as separate units on the highest level of classification. Although the definition of Brown earths is corresponding with the Cambisols reference group of WRB, correlation 
might be a problem. The cause of the problem is the definition of the Calcisols and their position in the key, before the Cambisols. If a Brown earth of the HSCS has a calcic horizon (carbonates $\geq 15 \%$ ) within $1 \mathrm{~m}$ (which is often the case, especially in eroded landscapes), they key out as a Calcisols RSG. The problem with the Calcisol definition and position in the key have been reported problematic in other countries as well and need to be reviewed by the WRB Working Group of IUSS.

\section{Sediment soils}

Sediment soils include soils with the presence of stratification within $50 \mathrm{~cm}$ from the soil surface as a result of accumulation of transported materials of various origin. Thus, the soil material of sediment soils was not developed in-situ, but transported and redeposited by erosion, or by fluvial or lacustrine processes. The stratification is required to be evidenced by the variation in texture/coarse fragment content, different colours or by not regular depth distribution of organic matter, or by the presence of a layer with 0.2 per cent higher OC content than the overlying layer within $1 \mathrm{~m}$. These criteria are providing a satisfactory correlation of Sediment soils of the diagnostic based HSCS with corresponding Fluvisols or Colluvic Regosols of WRB. Problematic situations may occur when the sediment have a calcic horizon (as described at the Brown earth discussion). In such cases the Sediment soils key out as Calcisols, which is not a satisfactory correlation in terms of taxonomic relationships (or similarities).

\section{Barren earths}

Other soils, that do not satisfy the requirements of any other soil type of the HSCS, thus, key out at the end of the classification key as Barren earth. Barren earths are generally shallow, weakly developed soils on unconsolidated parent material or on fragmented hard rock, usually on highly eroded or on very young surfaces. Barren earths correspond with the WRB Regosols.

\section{WRB reference groups that do not occur in Hungary}

Out of the 32 RSGs 20 are relevant in the Carpathian Basin. The WRB reference groups that do not occur in Hungary are mostly related to climatic or parent material differences. The below statement may be reviewed, if new surveys or investigations provide evidences of presence of the listed RSGs.

Cryosols are soils of the permafrost environment, hence only paleo (mostly buried) soils have fossil cryogenic features (BERÉNYI ÜvegEs, J. et al. 2003).

Andosols are soils developed from fresh glass-rich volcanic ejecta. Soils developed from volcanic parent material in Hungary are substantially weathered and developed, consequently, no Andosols have been documented in Hungary (Madarász, B. 2005).

Podzols are very acidic soils developing mostly under boreal forests. The criteria for the subsurface accumulation of iron and aluminium with or without organic matter are very strong in the WRB. National inventories do not include pedons that correspond with the WRB Podzols criteria (LÁNG, V. 2013). Local formations with limited extent, however, might be possible.

Plinthosols, Nitisols and Ferralsols are highly weathered soils of the tropics, and do not develop under the current climate of Hungary. Although paleo features of such soils have been documented by FeKETE, J. et al. (2006).

Planosols and Stagnosols are related to long term water logging and textural differentiation. Stagnic features are common mostly in the HSCS Clay accumulation soils and the Swelling clay soils, but pedons developing the required expression of the features are likely to occur, but were not documented.

Durisols are silica cemented soils of old arid and semi-arid areas and up till now, even paleo Durisols have not been documented in Hungary. 
Gypsisols are gypsum accumulation soils. Although gypsum is common in Solonetz and Solonchak soils and the Gypsic qualifier is an option to indicate the feature.

Retisols are typical for ice-age influenced soils with coarse bleached interfingering material into a clay rich subsurface in a net-like pattern. So far, no pedon with the feature has been documented.

Acrisols and Lixisol are clay accumulation soils of old surfaces, with low $(\leq 24 \mathrm{cmol} / \mathrm{kg})$ cation exchange capacity (CEC) of the clay. In Hungary the mineralogy of clay accumulation soils is characterized with much higher CEC (Stefanovits, P. 1963) and so far, no Acrisols or Lixisols were documented.

\section{Preserving legacy semantic and spatial soil information}

With the application of a computer assisted algorithm the earlier genetic classification units can be converted to the new ones, preserving the value of the legacy soil information (LÁNG, V. 2013; MichéLI, E. et al. 2014). The geographical distribution of the soil types of the modernized diagnostic-based HSCS is a greater challenge, as often no analytical data is supporting the spatial patterns. However, with the application of pedometric and digital soil mapping tools promising methodologies were documented by Doвоs, E. et al. (2014) and PÁsztor, L. et al. (2018) which can be adopted for the development of new national maps and correlated internationally understood maps.

The next and perhaps the most crucial test of the system is to map the new soil types (central units) and diagnostic categories and analyse their spatial patterns and their relationships with the physical geographic conditions of Hungary. An automated classification algorithm was developed to derive the classification units from legacy databases. With the application of the legacy data and new georeferenced field observations the spatial definition of new units is possible. This work is going on and will be subject of a follow up paper.

\section{Conclusions}

The 15 soil types defined in the diagnostic based, a modernized Hungarian Soil Classification System (HSCS) were developed based on the accumulated data and the genetic system. The introduced diagnostic approach with stronger morphogenetic and numerical criteria are not identical but correspond with the criteria of the classification units of the World reference base for soil resources. Although there are only few cases when one to one matching is possible, the adopted numerical criteria provide successful correlation results. Updating the national database and maps and the relevant correlated products is a challenge that needs substantial effort, however, promising methodologies have been documented.

Acknowledgement: This research was supported by the Higher Education Institutional Excellence Program (1783-3/2018/FEKUTSTRAT) awarded by the Ministry of Human Capacities and by Hungarian National Fund (OTKA) 113171 Program.

\section{REFERENCES}

Berényi Üveges, J., Horváth, Z., Michéli, E., Mindszenty, A. and Németh, T. 2003. Reconstructing Quaternary pedogenesis in a paleosol sequence in Hungary. Quaternary International 106. 61-71.

Cline, M.G. 1949. Principles of soil classification. Soil Science 67. 81-91.

Dobos, E., Vadnai, P., Bertóti, D., Kovác, K., Micheli, E., LÁng, V. and Fuchs, M. 2014. A novel approach for validating raster datasets with categorical data. In GlobalSoilMap basis of the global spatial soil information system. Eds.: Arrouays, D., McKenzie, N., Hempel, J., Richer de Forges, A. and McBratney, A., London, CRC Press, Taylor and Francis Group, 347-353.

Dokuchaev, V.V. 1883. The Russian Chernozem. Sankt Petersburg, Russia. (In Russian).

Farsang, A., Szolnoki, Zs., Barta, K. and Puskás, I. 2015. Proposal for the classification of anthropogenic soils in the framework of the updated Hungarian Soil Classification System. Agrokémia és Talajtan 64. 299-316. (In Hungarian)

Fenete, J., Szendrei, G. and Csibi, M. 2006. Characterization of Hungarian red soils. Agrokémia és Talajtan 55. (1): 29-38.

FILEP, G. 1999. A szikes talajok kémiai jellemzői közötti összefüggések (Correlations between the chemical 
characteristics of salt effected soils). Agrokémia és Talajtan 48. (3-4): 419-430.

Fuchs, M., Waltner, I., Szegi, T., LÁng, V. and MichéLI, E. 2011. Taxonomic distances of soil types in Hungary based on soil-forming processes. Agrokémia és Talajtan 60. (1): 33-44.

Hempel, J., Micheli, E., Owens, P. and McBratney, A. 2013. Universal soil classification system. Report from the International Union of Soil Sciences Working Group. Soil Horizons 54. (3): 1-6.

Hughes, P., McBratney, A., Huang, J., Minasny, B., Hempel, J., Palmer, D. and Micheli, E. 2017. Creating a novel comprehensive soil classification system by sequentially adding taxa from existing systems. Geoderma Regional 11. 123-140.

IUSS Working Group WRB, 2006. World Reference Base for Soil Resources. $2^{\text {nd }}$ edition. World Soil Resources Reports No. 103. Rome, FAO.

IUSS Working Group WRB, 2015. World Reference Base for Soil Resources 2014, update 2015. International soil classification system for naming soils and creating legends for soil maps. World Soil Resources Reports No. 106. Rome, FAO.

Jenny, H. 1941. Factors of Soil Formation. A System of Quantitative Pedology. New York, Dover Publications.

Jones, A., Montanarella, L. and Jones, R. (eds.) 2005. Soil Atlas of Europe. Luxembourg, European Soil Bureau Network European Commission.

LÁNG, V. 2013. Development of harmonization, correlation methods and data storage system to support soil conservation and international correlation. PhD dissertation. Gödöllő, Szent István University. (In Hungarian)

LÁNG, V., Fuchs, M., WAltner, I. and Michéli, E. 2010. Taxonomic distance measurements applied for soil correlation. Agrokémia és Talajtan 59. 57-64.

Láng, V., Fuchs, M., Waltner, I. and Michéli, E. 2013. Soil taxonomic distance, a tool for correlation: As exemplified by the Hungarian Brown Forest Soils and related WRB Reference Soil Groups. Geoderma 192. 269-276.

Madarász, B. 2005. Andosols: a vulkáni anyagon kifejlődött ásványi talajok (Andosols: soils developed on volcanic material). Agrokémia és Talajtan 54. (3-4): 509-516.

MiCHÉLI, E. 2011. Expression of soil-forming processes in soil classifications based on diagnostic principles. Agrokémia és Talajtan 60. (1): 17-32.
Michéli, E., Fuchs, M., Hegymegi, P. and Stefanovits, P. 2006. Classification of the major soils of Hungary and their correlation with the World Reference Base for Soil Resources (WRB). Agrokémia és Talajtan 55. (1): 19-28.

Michéli, E., Fuchs, M., LÁng, V., Szegi, T. and Kele, G. 2014. Methods for modernizing the elements and structure of the Hungarian Soil Classification System. Agrokémia és Talajtan 63. (1): 69-78.

Michéli, E., Láng, V., Owens P., Mc Bratney, A. and Hempel, J. 2016. Testing the pedometric evaluation of taxonomic units on soil taxonomy: A step in advancing towards a universal soil classification system. Geoderma 264. 340-349.

Minasny, B., McBratney, A.B. and Hartemink, A.E. 2009. Global pedodiversity, taxonomic distance, and the World Reference Base. Geoderma 155. 132-139.

Panagos, P. 2006. The European soil database (2006). GEO: connexion 5. (7): 32-33.

PÁsztor, L., Laborczi, A., BAKacsi, Zs., Szabó, J. and ILLÉs, G. 2017. Compilation of a national soil-type map for Hungary by sequential classification methods. Geoderma 311. (1): 93-108.

Stefanovits, P. 1963. The Soils of Hungary. $2^{\text {nd }}$ edition. Budapest, Akadémiai Kiadó. (In Hungarian)

Szabolcs, I. (ed.) 1966. OMMI Genetikus Talajtérképek (OMMI Genetic Soil Maps). Ser. 1. No. 9. Budapest, OMMI.

Szabolcs, I. (ed.) 1989. Salt affected soil. Boca Raton, CRC Press Inc.

Tavernier, R. and Smiths, D.G. 1957. The concept of Braunerde (Brown Forest Soil) in Europe and the United States. Advances in Agronomy 9. 217-289.

Tóth, T. and Várallyay, G. 2001. Past, present and future of the Hungarian classification of salt-affected soils. In Soil classification 2001. EUR 20398 EN. Eds: Micheli, E., Nachtergaele, F., Jones, R.J.A. and Montanarella, L., Luxembourg, Office for Official Publications of the European Communities, 125-135.

Várallyay, G., Szúcs, L., Zilahy, P., Rajkai, K. and Murányi, A. 1985. Soil factors determining the agro-ecological potential of Hungary. Agrokémia és Talajtan 34. 90-94. 
